\title{
English Language Teaching in the Kingdom of Saudi Arabia: Past, Present and Beyond
}

\section{Brendan Mitchell}

Doi:10.5901/mjss.2017.v8n2p317

\author{
Abdulrahman Alfuraih
}

\begin{abstract}
2014 realized the introduction of a comprehensive English language teaching curriculum, the English Language Curriculum for Elementary, Intermediate and Secondary Schools in the Kingdom of Saudi Arabia Grades 4 - 12, 2014 - 2020. This research paper seeks to provide an inclusive timeline of the development (English language) education from the time King AbdulAziz Ibn Saud united the Arabian Peninsula and created the Kingdom of Saudi Arabia. The chronology of English language curriculum reforms and education development provide evidence of a country seeking to define itself. Oil wealth drastically altered the Kingdom's fortunes and provided it with choices, development and opportunities. Recently, Tatweer Company for Educational Services in partnership with the Ministry of Education has provided customized English language textbooks and supplementary material complemented by a range of professional development programs. However, as recent research suggests there is more than needs to be done to support the continual improvement in the learning and teaching of English as the Kingdom continues to move into the developed world with less reliance on oil and a focus on becoming a knowledge based society. The Kingdom of Saudi Arabia's National Transformation Program and Vision 2030 support and provide the blueprint for this goal to be achieved.
\end{abstract}

Keywords: Education development, English language, reform, teaching initiatives

\section{Introduction}

The Kingdom of Saudi Arabia has been reforming its economy in recent years through a range of Saudization initiatives to increase national participation in the private sector and diversify its economy from one that is dominated by oil production and revenues. A key component of the reform initiatives is the role of education development where great emphasis has been put on subject areas such as STEM (science, technology, engineering and mathematics) and English language acquisition. The Kingdom is aiming to produce creative and critical thinkers with entrepreneurial skills and know-how who can thrive in an increasingly global world.

This article provides a chronology from the evolution of education in the Kingdom of Saudi Arabia, particularly English language education and the challenges the Kingdom faces to keep driving English language excellence forward. The later part of the article provides a research informed analysis of what challenges lie ahead for the Kingdom as it strives to the achieve the objectives of the English Language Curriculum for Elementary, Intermediate and Secondary Schools in the Kingdom of Saudi Arabia Grades 4 - 12, 2014 - 2020 and solutions that could be introduced to overcome the identified obstacles.

\section{Methodology}

In examining English Teaching in the Kingdom of Saudi Arabia: Past, Present and Beyond the methodology that has been used for the past and present sections is a literature review where relevant documents were collected and analysed. This enabled a timeline to be assembled to show how education has evolved in the Kingdom of Saudi Arabia and in particular English language teaching and learning.

The methodology used for the Beyond section of the paper was descriptive statistical analysis using the Statistical Package for Social Sciences (SPSS) to summarize the results of the analysis of the closed questions completed by Ministry of Education teachers. Two surveys were sent electronically to English teachers throughout the Kingdom of Saudi Arabia 2016; the first examined student attainment levels and garnered over 1200 responses; and the second survey looked at what could be done to support the continued improvement of the teaching of English in the Kingdom of Saudi Arabia which over 2500 teachers completed. The results data was then analysed following a thematic framework analysis adapted from Braun and Clarke's (2006) six phases of conducting a thematic analysis: familiarization with the (categorized) data set; generating initial data; searching for themes; checking identified themes; refining themes; and writing a research informed report. 


\section{In the beginning}

When writing about English language curriculum and teaching development in the Kingdom of Saudi Arabia, it is important to start with an account of the origins of the Saudi Arabian English language curriculum with special consideration to educational development generally and English language development specifically. As we know it today, the Kingdom of Saudi Arabia is a relatively young country that has gone through many changes, mainly due to economic prosperity brought from the riches of oil. Saudis were traditionally Bedouins, having their cultural origins as nomadic tribes who followed the rain and water sources for their herds of cattle; namely camels, sheep and goats. As the Kingdom of Saudi Arabia developed because of the monetary opportunity provided by oil revenues towns and cities and have become more urbanized.

Initially, formal education was limited to what was offered in mosques or provided by religious scholars with the focus being on the written and verbal memorization of the Holy Quran. The move to state controlled education dates back to the 1920s (Faruk, 2013). At that time, King AbdulAziz Ibn Saud united the Arabian Peninsula, and in 1925 established the precursor to the Ministry of Education, called the Directorate of Education, which still remains to this day. According to AL-Abdulkareem (1993), it was not until 1939 that formalized schools were established. These could be deemed as elementary schools with a total enrolment of only slightly more than 2,000 students. At that time and for several decades to follow, the Kingdom of Saudi Arabia relied on assistance from Egypt, Lebanon and Syria for its educational foundations, primarily due to a lack of national scholars and financial capacity (Al-Nafjan, 2012). Mahboob and Elyas (2014) note that the Scholarship Preparation School (SPS) was established in 1936 in Makkah and go onto say, "This school is considered to be the beginning of modern day high school education in the Kingdom of Saudi Arabia and the teaching of English in Kingdom of Saudi Arabia was first introduced in this school" (p. 129).

\subsection{The new era of the Saudi Arabian education system}

Despite the lack of national scholars and financial capacity, in 1950 the enrolment in elementary schools had grown to over 20,000 and with the new era of the Saudi Arabian education system in 1953 intermediate and secondary schools were developed and expanded (Alsenbl, et al. 1998). The model of education adopted corresponded to models of education in Egypt and Lebanon, which both adhered to a British model with many educational planners, administrators and curriculum developers within the Saudi Arabian Ministry of Education being Egyptian. According to Alshumaimeri (2012), the Ministry of Education in the Kingdom of Saudi Arabia, in the form it is today, was established in 1953; a time in which the Saudi constitutional monarchy started receiving significant royalties for oil. Because of the influx of oil revenues, Saudi teachers were sent abroad on scholarships to a diversity of locations including Egypt, Lebanon, the United States and Europe for teacher training.

During these early years of development, it is not surprising the Kingdom had a high level of reading and writing illiteracy due to the lack of exposure most of the population had to education. To address this issue and to encourage students from all parts of the Kingdom to attend schools, the government made education free and provided daily meals. This effort included the provision of transportation and textbooks as well as giving monthly allowances to students who came from needy families. For students who went onto study higher education within the Kingdom of Saudi Arabia, accommodation for students was provided free of charge and university students were provided with a monthly allowance of USD250 (AL-Abdulkareem, 1993). Although these early developments were largely focused on developing a literate Saudi Arabian population, the first evidence of education reform (such as teacher training, curriculums and the expansion and development of schools) started to take place in the 1950s coinciding with the influx of oil revenue (AL-Abdulkareem, 1993).

One of the down sides from the incentivized monthly allowance (which is still in place today and sometimes referred to by students as their salary) introduced for post-secondary study has been the expectation of teachers such incentives will be carried over into the workplace for current training and reform projects. In brief, incentive schemes for in-service teachers to attend and participate in training programs contribute to the tensions associated with current curriculum reform in the Kingdom of Saudi Arabia.

During the 1950s, a shift from the pre-1950 Egyptian model, which was British based, occurred and moved towards a more religious conservative alignment which has been evident in textbooks and school policies (Al-Nafjan, 2012). It was during this shift in 1949 that the first higher education college was established in Mecca and English was taught as a required subject for two hours per week for the duration of a four year college degree. As evidenced by Faruk (2013) who observed that it was also during this period that the United States (initially through the Arabian-American Oil Company (ARAMCO)) became more involved in the Kingdom of Saudi Arabia through its commercial interests in oil. 
This made English and English language teaching more relevant to Saudi Arabian economic and social development (Commins, 2008).

\subsection{The general administration for girls' education}

A further rather dramatic reform took place in 1960 with the establishment of the General Administration for Girls' Education which oversaw all levels of female education including teacher training colleges. The education system has always been and continues to be segregated by gender. Al-Salloom, (1991) provides the following reasoning for this segregation: "it must be understood that girls' education in separate institutions is mainly an issue related to the separate social status given to women by Islam" (p. 10). Al-Salloom (1991) elaborates on this by saying, "Islam is not only integral to Saudi Arabian education but also serves as the very essence of the curriculum" (10).

Dishon (1968) suggests one of the reasons for the introduction of education for females was so they would not be surprised when they saw the effects of television and education on women's progress (Dishon, 1968) in terms of clothing and women's roles in society. Dishon (1968) goes on to discuss the education of women being a necessity. Both of these assertions made by Dishon (1968) can be attributed to the Kingdom of Saudi Arabia's increased wealth and attempt to balance internal and external socio-political changes influencing Saudi women (Al-Rasheed, 2013).

\subsection{The 1970 Ministry of Education English language teaching framework}

1970 saw the release of the inaugural Ministry of Education English language teaching framework and syllabus at the secondary level. The general aims of the syllabus included providing secondary school students a window on the world, providing students with the opportunity to read science and arts literature in English, developing critical thinking and imaginations, and providing students with the English proficiency to enter university and/or pursue their vocation. The aims of the syllabus were complemented by the objectives which were for students to develop mastery of the four main English skills (reading, writing, speaking and listening), for students to understand the value of learning a foreign language for economic, social and cultural purposes; and to develop students' interest in reading particularly for future purposes. It was from these objectives that the textbooks were written with adherence to Saudi Arabian culture.

The use of customized textbooks produced by international publishers that go through a review process in the Ministry of Education for students is still the practice today with yearly renewed editions of the materials. It was also during the early 1970s that private schools for both boys and girls started teaching English from the first grade. Private schools for girls had been operating from the late 1950's (Commins, 2008) and followed the national curriculum. They were attended by the children of the business elite and Royal Family (Commins, 2008).

While the 1970 English language teaching framework proclaimed the goals and objectives of critical thinking through reading an array of literature and opportunity to engage with the outside world, the general curriculum remained conservative. The Kingdom of Saudi Arabia's education policy of 1970, while being religious in its nature, does not mention denunciation of other faiths. This non-inclusion could be dependent on the individual teacher's views and education where many teachers graduated with studies in religious studies (Commins, 2008). This could lead to different interpretations of the textbooks and syllabus guidelines which emphasized such traits as: the strength of faith in Islam; being guided by the message of Mohammad; the importance that each Muslim should seek education; the importance of national history; and the incorporation and teaching of religion in all levels and schooling. The teaching of Islam was also integrated into subject areas such as science, where feasible, to promote solidarity, respect and faith in Islamic society without prejudice on the grounds of ethnicity and location and the duty to share Islam globally. It should be noted that the Third (1980-1985) National Development Plan placed a greater emphasis on the use of instructional technology to improve teaching and learning practices. So while the curriculum could be seen to be structured around Islam, the use of modern teaching aids was encouraged. However, the use of technology in the classroom creates tension for teachers in its use due to lack of training and facilities (Mulhim, 2014).

1988 saw the introduction of a revised English language curriculum with a more functional approach towards the English language. This emphasis was seen as one of the distinctions of this new curriculum.

\subsection{The expansion of English language education in public schools}

"The continuous drive for quality education led to the Ministry of Education to launch in 2000 a project of comprehensive revision of its educational curriculum and teaching materials at all levels: elementary, intermediate and secondary" (AlSaadat \& Al-Braik, 2004, p. 201). English language teaching was included in the project to improve the teaching of skills 
of teachers and how to teach the curriculum. The focus was not so much on the curriculum but on the instruction and assessment of the curriculum because these are the areas where teachers have needed in-service professional development on (Commins, 2008).

A year after the launch of the project to revise the curriculum, the terrorist attacks of September 11, 2001 occurred and education systems in the Islamic world were blamed, particularly the Saudi Arabian education system, as fifteen young Saudis were involved in the operation (Taleb, 2005). However, "a study in education (assigned by the Arab Education Bureau of the Gulf States), in the Gulf States suggests that the events of 9/11 are the associations made between the education systems of the Arab world and terrorists and extremists" (Taleb, 2005) and Arab education are not to blame as those responsible did not attend mainstream schools. However, officials from within the governments of the United States and the Kingdom of Saudi Arabia expressed concerns that the curriculum did not promote tolerance and there was a need for education reform (Center for Religious Freedom with the Institute for Gulf Affairs, 2006). Regardless of the findings of the study (Taleb, 2005), encouragement on education reform in the Arab world was pushed as curricula in their current state were not capable of developing human resource capacity and capability to compete in a globalized world.

A new Ministry of Education English language curriculum was introduced in 2004 with the objectives not differing greatly from what was introduced in 1970. This introduction coincided with the teaching of English from grade six in public schools and paved the way for the introduction of English teaching and learning at elementary schools. The objectives could be seen as an extension or revised version with most notable of these being the transfer of knowledge and spreading the Islamic faith (Ministry of Education, 2005).

The Ministry of Economy and Planning (2006) noted that the enhancement of English language teaching has become one of the development strategies in the Kingdom of Saudi Arabia, recognizing the importance of English language proficiency for the continued development of the Kingdom of Saudi Arabia. The Kingdom of Saudi Arabia has traditionally funded scholarships for education purposes since it evolved into a Kingdom. This has been increased since 2005 where the King Abdullah scholarship program has provided opportunities for tens of thousands of Saudi Arabian students to study abroad to contribute to the development strategies of the Kingdom of Saudi Arabia upon their return.

There have been tensions associated with the various recent reform efforts in Kingdom of Saudi Arabia. Some argue (Taleb, 2005) such reforms are propaganda based on the English curriculum objective of spreading the word of Islam. Others are opposed to sending young Saudis abroad arguing those going abroad will adopt Western values which are against the teachings of Islam (Taleb, 2005).

\subsection{Recent reform efforts}

The most recent reform efforts are encapsulated in the King Abdullah bin Abdulaziz Public Education Development Project (also known as the Tatweer Project) which was developed as a five year initiative (2008 - 2012) by the Ministry of Education to revive the reform efforts of the Kingdom's public schools as the Sixth Plan for Educational Development in the Kingdom of Saudi Arabia. The foundation of the reform was grounded in the potential human capital benefits associated with education as a predictor of national development and global social and economic participation. The vision of the project, at the time, was to create a world-class and self-sustaining knowledge workforce that can compete effectively at the global level. Building on prior reform initiatives in the Kingdom of Saudi Arabia, Tatweer aims to create a new framework for teaching and learning, which would contribute to both individual and national economic development. The King Abdullah Public Education Development Project (Tatweer) has been expanded since 2012 with particular recognition for both, science, technology, engineering and mathematics (STEM) and English language teaching (ELT) to reflect their importance for potential labour market participation and knowledge economy development. Extra-curricular activities, community participation projects, Arabic language, school leadership, technology, professional learning communities and professionalizing the teaching professional are initiatives contributing to the overall improvement of teaching and learning in the Kingdom of Saudi Arabia. The investment in public school education is complemented with the investment in higher education and vocational educational (Wiseman, et al., 2014) to prepare graduates for the private sector and stem the unemployment of the young in a country of high birth rates (Commins, 2008).

\subsection{English language teaching initiatives: $2013-2015$}

2013 heralded the release of the English Language Curriculum for Elementary, Intermediate and Secondary Schools in the Kingdom of Saudi Arabia Grades 4 - 12, 2014 - 2020. Coinciding with this important document was the development of the working relationship and in essence partnership between the Ministry of Education (English language) curriculum 
division and Tawteer Company for Educational Services English Language Teaching Development Initiative. This resulted in the provision of (through Tawteer Company for Educational Services) customized English language teaching textbooks and their accompanying supplementary material which is supplied by three contracted international publishing partners. The English language teaching materials are now standardized and aligned to a comprehensive national curriculum and adhere to Saudi Arabian culture and principals. The student and workbooks are all printed in the Kingdom of Saudi resulting in improved efficiency and logistical effectiveness. These functions are managed and controlled internally with the supporting materials hosted on the Tatweer National Educational Portal accessible to all teachers and students.

Complementing the introduction of the new Saudi Arabian English language curriculum and accompanying textbooks have been significant professional development activities implemented by Tatweer in partnership with the Ministry of Education (the English language supervision division supported by the curriculum division) which have included; English language proficiency testing, pedagogical skill development, the effective use and teaching of the textbooks and English language proficiency training. These programs have benefited thousands of participating teachers but cannot be seen to be continuing professional development programs as training needs and pathways have yet to be established to meet individual teacher needs for the approximately 35,000 English language teachers across the Kingdom of Saudi Arabia.

\section{Where to from here?}

In 2016 two surveys were sent electronically to English teachers throughout the Kingdom of Saudi Arabia. This section presents and describes the results of the relevant Likert-type data the surveys generated which could influence the direction and drive the constant improvement in the teaching and learning of English throughout the Kingdom of Saudi Arabia.

Table 1 reveals that contemporary teaching pedagogies are present in English classrooms in the Kingdom of Saudi Arabia with over $90 \%$ of teachers reporting to use a variety of activities in their classes and close to $85 \%$ of teachers providing students with on-going assessment and feedback on their progress. Students are motivated and enjoy studying English and the responses indicate motivation is higher (close to 70\%) when the teachers use online and digital material to stimulate student learning. However, while Table 1 presents positive indicators, student ability does not match their grade level evidenced by teachers reporting that only slightly more than $40 \%$ of their students have the ability to succeed in their grade levels.

There are two factors that have been identified as contributors to students' abilities not matching their grade level. First, while the majority of teachers set homework for their students not all of their students are completing the homework tasks. Table 1.1 supports this notion by showing that while students are motivated by online and digital material, surprisingly $26.14 \%$ of students only access the online and digital material occasionally and $32.74 \%$ of students never access the material. The second contributing factor is that students need more English classes per week. The majority of the teachers (slightly more than 65\%) think that students should be exposed to learning English prior to the fourth grade.

Table 1: Student motivation and ability

\begin{tabular}{lcccc}
\hline & \multicolumn{3}{c}{ N (\%) } \\
\hline & Strongly Agree & Agree & Disagree & Strongly Disagree \\
\cline { 2 - 5 } The textbooks are suitable for the level of my students & $188(14.87)$ & $555(43.91)$ & $337(26.66)$ & $184(14.56)$ \\
The online/digital learning material motivates my students & $307(24.40)$ & $564(44.83)$ & $274(21.78)$ & $113(8.98)$ \\
Students need more English classes each week & $564(44.73)$ & $307(24.35)$ & $256(20.30)$ & $134(10.63)$ \\
My students' English levels match their grade level & $99(7.91)$ & $435(34.74)$ & $500(39.94)$ & $218(17.41)$ \\
My students are motivated to learn English & $198(15.84)$ & $541(43.28)$ & $375(30)$ & $136(10.88)$ \\
My students enjoy studying English & $224(17.82)$ & $589(46.86)$ & $357(28.40)$ & $87(6.92)$ \\
I give my students homework & $552(44.05)$ & $615(49.08)$ & $70(5.59)$ & $16(1.28)$ \\
My students complete their homework and assignments & $161(12.75)$ & $611(48.38)$ & $391(30.96)$ & $100(7.92)$ \\
I use a variety of activities to motivate my students & $511(40.33)$ & $653(51.54)$ & $85(6.71)$ & $18(1.42)$ \\
I use progress tests to measure my students' improvement & $370(29.23)$ & $684(54.03)$ & $179(14.14)$ & $33(2.61)$ \\
I provide students with feedback on their progress & $390(30.81)$ & $672(53.08)$ & $158(12.48)$ & $46(3.63)$ \\
\hline
\end{tabular}


Table 1.1: Student use of the online and digital material provided by the publishers

\begin{tabular}{cc}
\hline Frequency & $\mathrm{N}(\%)$ \\
\hline Always & $79(3.08)$ \\
Often & $203(7.92)$ \\
Sometimes & $772(30.12)$ \\
Occasionally & $670(26.14)$ \\
Never & $839(32.74)$ \\
\hline
\end{tabular}

Table 2 reinforces the results from Table 1 in regard to students' levels of English not equating to their grade level. The responses show almost all of the teachers surveyed have what they deem to be a percentage of students in their classes with low levels of English attainment; some more so than others. Positively, over $80 \%$ of the respondents reported that they have the teaching skills to help students with low levels of English attainment.

Table 2: Percentage of students with low levels of English attainment

\begin{tabular}{cc}
\hline English attainment levels & $\mathrm{N}(\%)$ \\
\hline None of my students have a low level of English attainment & $42(3.33)$ \\
$5 \%-25 \%$ & $510(40.38)$ \\
$25 \%-50 \%$ & $392(31.04)$ \\
$50 \%-75 \%$ & $271(21.46)$ \\
$75 \%-100 \%$ & $48(3.80)$ \\
\hline
\end{tabular}

Tables 4 and 5 present the data on the percentage of Arabic, English teachers use in their classrooms and the reasons why they need to resort to using Arabic in English language classes. More than $60 \%$ of the teachers who completed the survey reported to use Arabic for $30 \%$ of the time in their classes while close to 405 of the teachers reported using Arabic more than $30 \%$ of the time in their classes. The majority of the reasons given for using Arabic in the classroom related to student attainment and levels of understanding. The other prominent reason provided by the survey teachers corresponds with what was reported in Table 1 in regard to homework and self-study; students do not prepare (read and study new vocabulary) prior to classes.

Table 4: Percentage of Arabic teachers use in the classroom

\begin{tabular}{cc}
\hline Arabic & $\mathrm{N}(\%)$ \\
\hline $0-10 \%$ & $507(19.78)$ \\
$11-20 \%$ & $529(20.64)$ \\
$21-30 \%$ & $560(21.85)$ \\
$31-50 \%$ & $476(18.57)$ \\
$51-70 \%$ & $332(12.95)$ \\
$71+\%$ & $159(6.20)$ \\
\hline
\end{tabular}

Table 5: Why teachers use Arabic in the classroom

\begin{tabular}{lc}
\hline Reasons why teachers use Arabic & $\mathrm{N}(\%)$ \\
\hline So my students understand me & $1,234(48.97)$ \\
To save time & $635(25.20)$ \\
My English is not very good & $167(6.63)$ \\
So I do not have to repeat instructions & $192(7.62)$ \\
My students do not understand a lot of the vocabulary & $1,618(64.21)$ \\
My students are motivated when I teach English using Arabic & $640(25.40)$ \\
I use the grammar translation method of teaching English & $846(33.57)$ \\
My students ask me to use Arabic & $858(34.05)$ \\
I cannot explain everything to my students in English & $472(18.73)$ \\
The books are difficult for the students & $824(32.70)$ \\
My students do not do homework & $347(13.77)$ \\
My students do not read about the lesson before class and learn the new vocabulary before class & $1,096(43.49)$ \\
It is easier for me to use Arabic & $133(5.28)$ \\
I use Arabic to give instructions & $52(20.67)$ \\
\hline
\end{tabular}

Tables 1 to 5 have predominantly focused student deficiencies in learning English. The areas (method, testing and student feedback) in Table 1 that examined possible teacher deficiencies established teacher competency based on their responses. However, this may not reflect the true picture. The following sections have identified some of the areas 
teachers may lack competency in and require professional development programs to up-grade their teaching skills. The article does not look for reasons for why teachers may not be adequately equipped for the classroom which can be traced back to the content of teacher education programs (Alhamzi, 2003; Al-Seghayer, 2014; and Al-Nasser, 2015). Rather we have focused on what is needed for in-service teachers now and in future years to improve the teaching and by effect learning of English throughout the Kingdom of Saudi Arabia.

Saudi Arabian English graduates are not required to sit an internationally benchmarked English proficiency test in order to apply to be an English teacher at the Ministry of Education though they are required to sit a national English language test called STEP provided by Qiyas. Some teachers on their own accord and others through participation in Tatweer Company for Educational Services' training programs have sat either and IELTS or TOEFL. For those teachers who reported to have sat either of the international tests and reported their score in the survey, the results are very positive with over $60 \%$ of the teachers reporting to have achieved an IELTS 6 (or TOEFL equivalent) or higher.

However, we would suggest this may not be an accurate reflection of the actual English proficiency levels of English teachers throughout the Kingdom of Saudi Arabia. This assumption is based on IELTS equivalency test results from English pre-tests conducted by Tatweer Company for Educational Services in partnership with the Ministry of Education for approximately 6000 male and female teachers dispersed somewhat evenly across Riyadh, Jeddah, the Eastern Province, Makkah and Al Madinah. The English pre-test results showed that slightly less than $20 \%$ of the English tested achieved an IELTS equivalent of 6 or higher. It must be noted that the teachers who sat the pre-test did not have the opportunity to do any test preparation, were unfamiliar with the delivery mode of the pre-test and there were some logistical challenges to overcome (with the majority of the approximately 6000 teachers tested over four days). We assume that if the teachers had prior knowledge of the test, results would have been higher.

\section{Teachers Needs}

Over $70 \%$ of the teachers who completed the survey deem themselves in need of English proficiency classes and by implication the testing that accompanies the training. This can be seen a positive in that teachers have self-identified the need for skill development training.

Table 6 reveals that the two main areas teachers identified needed training in, which are English proficiency (and grammar, using English in the classroom and vocabulary) and teaching low level students. The other areas that teachers identified they need professional development programs in are: technology in the classroom which is interlinked with textbooks; a range of pedagogies; motivating students; homework, preparation and assessment and classroom and time management strategies. Professional development programs that incorporate lesson planning and assessing students should result in teachers dedicating more time to these activities which will contribute to the improvement teaching practices.

Table 6: The areas teachers have identified they need training in

\begin{tabular}{lc}
\hline Training need & $\mathrm{N}(\%)$ \\
\hline English (listening, speaking, reading and writing) skills & $1,114(44.65)$ \\
Pedagogy & $312(12.51)$ \\
Grammar & $419(16.79)$ \\
Vocabulary & $530(21.24)$ \\
Using the textbooks and the publishers' online and digital material & $671(26.89)$ \\
Technology in the classroom & $849(34.03)$ \\
Active learning & $876(35.11)$ \\
Teaching low level students & $1,000(40.08)$ \\
Student motivation & $695(27.86)$ \\
Classroom management & $316(12.67)$ \\
Lesson planning and preparation & $358(14.35)$ \\
Giving and correcting homework & $202(8.10)$ \\
Flipped classroom & $292(11.70)$ \\
Time management & $447(17.92)$ \\
Using English in the classroom & $442(17.72)$ \\
Assessment & $312(12.51)$ \\
Teaching young learners & $527(21.12)$ \\
Using games to teach English & $95(38.16)$ \\
\hline
\end{tabular}




\section{Discussion}

This paper has provided a comprehensive overview of the development of (English language) education in the Kingdom of Saudi Arabia where the development of education can be seen to have been "intensely historical, political, racial, gendered, phenomenological, autobiographical, aesthetic, theological and international" (Pinar, Reynolds, Slattery, Taubman, 1995, pp. 847- 48). Furthermore, the paper identified, through the results of surveys completed by Ministry of Education English teachers throughout the Kingdom of Saudi Arabia that while significant developments in English language teaching and learning have been implemented in the Kingdom there are still challenges to be met. Two significant themes have emerged from the paper with and two outcomes from the research have become apparent as to why the goals and objectives in the English Language Curriculum for Elementary, Intermediate and Secondary Schools in the Kingdom of Saudi Arabia Grades 4 - 12, $2014-2020$ are not fully being achieved.

First, from the early 1950s when the Kingdom started to receive significant oil royalties the Kingdom has been able to chart its own destiny without being dependent on assistance from neighbouring countries. In addition to controlling the content of national curricula participation rates in across all levels of education have continued to increase since the 1950s which witnessed a spike in attendance and then again in the 1960s with the introduction of girls education.

The second major theme to emerge is that English language is seen as a tool for economic development and a demonstration of a nation committed, through Educational processes, to cultivating and, potentially, reconstructing a future citizen and society that is academically oriented and prepared, possessing the critical thinking skills who will shape the future of the Kingdom of Saudi Arabia in its drive to move towards a knowledge based economy. However, following this theme is the first outcome from the data section of the paper; student attainment, ability and (perhaps) application lag behind the documented goals and objectives of the English language curriculum document. Some of the suggested solutions to address students with low levels of student attainment are; more English classes (and introduce English classes earlier) and/or provide online learning options for students and encourage more parental involvement in the teaching and learning process to motivate students.

The second outcome revolves around teachers' needs. There is a need for structured professional development programs for teachers in a range of areas; curriculum, textbooks, pedagogies, proficiency, time management, motivating and engaging the students and (perhaps) teaching mixed level classes. The pedagogy training is coupled with the high number of teachers who reported they need English proficiency training indicates that a range of measures need to be introduced to improve teaching practices and strive towards excellence in teaching and learning (of English) throughout the Kingdom of Saudi Arabia. The release of the National Transformation Plan 2020 and the Vision 2030 for the Kingdom of Saudi Arabia express the Kingdom's future goals and will provide both motivation and structure for improved educational outcomes and opportunities for Saudis in general.

\section{Summary}

This paper has provided a comprehensive overview of the development of (English language) education in the Kingdom of Saudi Arabia where the development of education can be seen to have been "intensely historical, political, racial, gendered, phenomenological, autobiographical, aesthetic, theological and international" (Pinar, et al.,1995, pp. 847- 48). Furthermore, the paper identified, through the results of surveys completed by Ministry of Education English teachers throughout the Kingdom of Saudi Arabia that while significant developments in English language teaching and learning have been implemented in the Kingdom there are still challenges to be met.

\section{References}

AL-Abdulkareem, S. (1993). Educational development in Saudi Arabia (Historical project). Retrieved from www.faculty.ksu.edu.sal Al-Hazmi, S. (2003). EFL teacher preparation programs in Saudi Arabia: Trends and challenges. TESOL Quarterly, 37(2), pp. $341-344$. Al-Nafjan, E. (2012, April 23). Teaching Intolerance. Foreign Policy. Retrieved from http://www.foreignpolicy.com/articles/2012/04/23/teaching_intolerance

Al-Nasser, A.S. (2015). Problems of English language acquisition in Saudi Arabia: an exploratory-cum-remedial study, Theory and Practice in Language Studies, 5(8), pp. 1612-1619.

Al-Rasheed, M. (2013). Most masculine state: gender, politics, and religion in Saudi Arabia. Cambridge: Cambridge University Press.

Al-Saadat, A. E. \& Al-Braik, M. S. (2004). Assessing the roles of teachers and supervisors of English as a foreign language in the reform of English language curriculum in Saudi Arabia. Scientific Journal of King Faisal University (Humanities and Management Sciences), 5(1), $197-214$.

Al-Salloom, H. I. (1991). History of educational movement in the Kingdom of Saudi Arabia. Washington: International Grafeix. 
Al-Seghayer, K. (2014). The actuality, inefficiency, and needs of EFL teacher-preparation programs in Saudi Arabia. International Journal of Applied Linguistics \& English Literature 3(1), pp. 143-151.

Alsenbl, A., Alkhateeb, M., Motuali, M., \& Abduljwad, N. (1998). Educational system in the Kingdom of Saudi Arabia. Riyadh: Alkhurigy.

Alshumaimeri, Y. (2012). Education in Saudi Arabia. Retrieved from www.faculty.ksu.edu.sa

Braun, V. and Clarke, V. (2006). Using thematic analysis in psychology. Qualitative Research in Psychology, 3(2), 77-101.

Center for Religious Freedom with the Institute for Gulf Affairs (2006). Saudi Arbia's curriculum of intolerance. Center for Religious Freedom. Retrieved from https://freedomhouse.org/sites/default/files/CurriculumOflntolerance.pdf

Commins, D. D. (2008). The Wahhabi Mission and Saudi Arabia. London: I.B.Tauris \& Co. Ltd.

Dishon, D. (1968). Middle East Record, volume 4, 1968. New York: John Wiley \& Sons.

Faruk, S. G. (2013). English language teaching in Saudi Arabia: A world system perspective. Scientific Bulletin of the Politehnica University of Timişoara Transactions on Modern Languages, 12(1-2) 73-80.

Mahboob, A. and Elyas, T. (2014). English in the Kingdom of Saudi Arabia. World Englishes 33(1) 128-142.

Ministry of Economy and Planning, Kingdom of Saudi Arabia (2006). Eighth Development Plan (2005- 2009).

Ministry of Education, Kingdom of Saudi Arabia (2005). Goals of English Language Teaching.

Ministry of Education, Kingdom of Saudi Arabia (2013). English Language Curriculum for Elementary, Intermediate and Secondary Schools in the Kingdom of Saudi Arabia Grades 4 - 12, 2014 - 2020.

Mulhim, E. A. (2014). The barriers to the use of ICT in teaching in Saudi Arabia: A review of literature. Universal Journal of Educational Research 2(6): 487-493, DOI: 10.13189

Pinar, W. F., Reynolds, W. M., Slattery, P., \& Taubman, P. M. (1995). Understanding curriculum: An introduction to the study of historical and contemporary curriculum discourses. New York: Peter Lang.

Taleb, S. A. (2005, September 6). Changing the national curriculum of Saudi Arabia. Islam Daily. Retrieved from http://www. islamdaily.org/en/saudi-arabia/3438.changing-the-national-curriculum-of-saudi-arabia.htm

Wiseman, A. W., Alromi, N., \& Alshumrani, S. (Eds.). (2014). Education for a Knowledge Society in Arabian Gulf Countries. Volume 24 International Perspectives on Education and Society Series. Bingley: Emerald Publishing. 